\title{
A LEGAL HISTORY OF THE NEW ZEALAND JURY SERVICE - INTRODUCTION, EVOLUTION, AND EQUALITY?
}

\author{
Michèle Powles*
}

This paper traces the development of the New Zealand jury system. Most noteworthy in this development has been the lack of controversy the system has created. At the end of the nineteenth century however, the pursuit of equality in the legal system generally, led to debate and reform of juries in relation to representation, race and gender.

\section{INTRODUCTION}

One of the most fundamental institutions of Common Law legal structures is the jury system. The most noticeable aspect of the system in New Zealand is the lack of controversy that the development of this institution has created. Indeed the history of New Zealand juries has been almost entirely neglected. ${ }^{1}$

This can be explained in part by the fact that although the jury system was of great constitutional importance, it was and still is seen in practice as a rather mundane matter. Moreover, it is suggested that the lack of controversy about the New Zealand jury system stems from its clear correlation with New Zealand's social development. The theory of any parliamentary democracy is of course that legislation should follow social trends. However, the New Zealand jury system has done this with unusual consistency. Indeed it was only at the end of the nineteenth century that the New Zealand jury system became connected with any controversy.

* This is an edited version of a paper submitted in fulfilment of the VUW LLB(Hons) legal writing requirement.

1 Jim Cameron makes a brief study of some aspects of the system in John Robson ed The British Commonwealth: The Development of its Laws and Constitution. Volume 4 (2 ed, Stevens and Sons, London, 1967) 93-98. [The British Commonwealth] As does Peter Spiller, Jeremy Finn and Richard Boast A New Zealand Legal History (Brookers Ltd, Wellington, 1995) 
This paper gives a brief introduction to the historical evolution of the jury system in New Zealand. The information has been arranged in chronological order and divided into four sections in an attempt to make this historical evolution more accessible. The paper therefore begins with the importation of the jury system into New Zealand in the precolonial period. Next, it looks at the system's original formulation and later adaptation in the early colonial period. Thirdly, the period of growth and expediency until approximately 1890 is examined.

In the later years of New Zealand's jury system the most controversial issues were the continuing struggle for legal equality in representation on jury lists: between the defendant and the accused, interracially, and between the sexes. These issues are reflected in the debates and reforms in the jury system. Because of their detail, importance and the fact that they are spread across chronological eras, they have been treated as separate case studies.

\section{HISTORICAL OUTLINE}

After its discovery by James Cook in 1769, New Zealand developed rapidly into a country that Britain clearly coveted for colonisation. ${ }^{2}$ But it was not until the 1830's that Britain seriously took up the idea of annexation of New Zealand. New Zealand Maori signed the Treaty of Waitangi in 1840 and New Zealand became a settled ${ }^{3}$ territory attached to New South Wales. ${ }^{4}$

Unlike New South Wales however, New Zealand was wanted for civilian colonisation. ${ }^{5}$ As a Crown colony it was to be self-supporting and self-governing and to this extent a rush of legislation including a Jury Ordinance was quickly imported in 1841 for the regulation of British civilians, settlers and traders. Initial jury legislation needed to change quickly to adapt to New Zealand's specific circumstances, not least of which was the presence of

2 J M Owens "New Zealand before Annexation" in Geoffrey W Rice (ed) Oxford History of New Zealand (2 ed, Oxford University Press, Auckland, 1981) 28, 28-29 [Oxford History].

3 There is still debate over whether New Zealand was settled or ceded. It has been suggested however that New Zealand courts would have been bound to recognize and apply Maori law had New Zealand been a ceded territory. No court has yet applied Maori law (as opposed to custom) in New Zealand. The British government certainly treated New Zealand as a settled colony in legislation (including jury legislation). Philip A Joseph Constitutional and Administrative Law in New Zealand (The Law Book Company, Sydney, 1992) 32-34 [Constitutional and Admin Law].

4 Letters Patent of 1839 altered the boundaries of New South Wales to include New Zealand but the Colonial Office did not express its sovereignty over New Zealand until after the signing of the Treaty of Waitangi in 1840. Constitutional and Admin Law above n 3, 30.

5 W J Gardner "A Colonial Economy" in Oxford History above n 2, 57, 58. 
another race. New Zealand was granted its own constitution in $1852 .{ }^{6}$ This led the way for self-governance and eventually party politics.

\section{PRE COLONIAL PERIOD 1830-1840}

The origins of the New Zealand jury system stem from the long history of the institution in England. It observed the distinction between fact and substantive law and even though the use of civil juries declined in later years, ${ }^{7}$ "[i]t was to become a constitutional principle sacred to generations of Englishmen that men should be judged by their peers". 8

Given the importance placed on the jury system in England, it is not surprising that it was the subject of one of the first pieces of legislation in New South Wales and New Zealand. ${ }^{9}$ Although British nationals from New Zealand could be tried extraterritorially by jury in New South Wales from $1828,{ }^{10}$ there was no provision for jury trial in New Zealand until legislation was imported directly from Britain in 1841. Both the New South Wales and the later New Zealand legislation were clearly based on the English Act of 1825. ${ }^{11}$

The jury legislation of New South Wales was operative as early as $1829 .{ }^{12}$ However, New South Wales was created as a penal colony ${ }^{13}$ and therefore major variations from the English processes of trial were apparent. ${ }^{14}$ Indeed the colony had far more problems in accepting the need for trial by one's peers than did New Zealand. The New South Wales

6 Raewyn Dalziel "The Politics of Settlement" in Oxford History above n 2, 87, 91-92.

7 J H Baker Introduction to English Legal History (2 ed, Butterworths, London, 1979) 81 [Introduction to English Legal History]. The use of civil juries other than in defamation cases also seems to have all but disappeared in New Zealand.

8 Introduction to English Legal History above n 7, 66.

9 Provision for juries in New South Wales (NSW) was actually granted by an English Act in 1828 . An Act to Provide for the Administration of Justice in New South Wales and Van Dieman's Land 1828 (UK) 9 Geo IV c 83, s 8. But it was first established by NSW legislation by the Juries Act 1829 (NSW) 10 Geo IV No VIII. The provision was made for New Zealand in the Juries Ordinance 1841.

10 An Act to Provide for the Administration of Justice in New South Wales and Van Dieman's Land 1828 (UK) 9 Geo IV c 83, s 4 and 8.

11 However, the New Zealand copy was in a far less verbose form than either the English or NSW legislation.

12 Juries Act 1829 (NSW) 10 Geo IV No VIII.

13 New South Wales Act 1787 (UK) 27 Geo IV, c 2, B and C 18.

14 Alex Castles An Australian Legal History (The Law Book Company, Sydney, 1993) 47 [An Australian Legal History]. 
jury system was based, for convicts and civilians alike, on military control. ${ }^{15}$ Indeed many of the administrators in New South Wales had an intense distrust of anything nonmilitary. ${ }^{16}$ The absence of the civil jury was a source of bitter dispute and agitation continued against both the New South Wales authorities ${ }^{17}$ and the British government. ${ }^{18}$ By 1840 however civil juries were the norm and military juries for civilians were no longer in operation. ${ }^{19}$

\section{COLONIAL PERIOD 1840-1852}

In contrast to New South Wales the New Zealand jury system was brought in with both expediency and a lack of controversy in 1841. Like New South Wales however, New Zealand adapted this legislation to fit its situation. In New South Wales this had meant an emphasis on military control. But in New Zealand the legislation was merely simplified to fit with the status of the country as a colony in its infancy. Thus the New Zealand version of the English Act from 1825 maintained the same substantive provisions but reduced the text considerably. ${ }^{20}$

\section{A Formulation of the New Zealand System}

The New Zealand Ordinance covered briefly and succinctly the basic precepts of the English system. Qualification was by sex (male) and the property franchise, ${ }^{21}$ but men in

15 An Australian Legal History above n 14, 47

16 An Australian Legal History above n 14, 204. In 1836 for example, Burton J of the Supreme Court showed his distaste for civilian juries, at least where these might not consist of the "gentlemen" he considered were the only ones suited for jury service. He affirmed there was a want of confidence in juries on the part of civil inhabitants.

17 An Australian Legal History above n 14, 53.

18 An Australian Legal History above $\mathrm{n}$ 14, 54. Indeed even with the introduction of civil juries, military ones continued and civil juries were subject to much pressure and scrutiny. An Australian Legal History above n 14, 272.

19 An Australian Legal History above n 14, 203.

20 From the 16 pages of the English Act to a mere page of text in a similar format in the New Zealand Ordinance.

21 The property franchise at this stage consisted of having for "his own use a freehold Estate in lands and tenements within the colony". Jury Ordinance 1841, s 1. 
official occupations were exempt. ${ }^{22}$ Men of unsound mind ${ }^{23}$ or unsuitable character were ineligible for service. ${ }^{24}$ The men were to be ordered alphabetically and the list would stand until superseded by a new order in the next year's list. ${ }^{25}$ Ballot was used early in New Zealand and 12 men were selected from $36 .{ }^{26}$ There was also provision to make up the numbers with "good and lawful men of the bystanders".27

The verbosity of the English provisions was not followed in New Zealand, but it is clear that the sense of importance of the institution was. Even at this early stage in New Zealand's development, failure to appear for jury service without "reasonable excuse" incurred the substantial penalty of 10 pounds. ${ }^{28}$

The great importance placed on the jury mechanism may seem out of proportion given the primitive development of the New Zealand judicial system at this stage. However, when the purpose of the jury system in New Zealand is explored, this importance appears justified. The jury system, held a place of great historical importance for the British. A jury was, and still is to a certain extent, seen as a characteristic of traditional "British liberties".29 It is suggested therefore that some of the importance attached to this system stemmed from an attempt to ensure that the New Zealand institutional structure maintained a "civilised British" countenance. Also, initially at least, the Colonial Office wanted to maintain a high level of control in these far-off colonies. ${ }^{30}$ As a clearly recognisable part of the Colonial system, the jury system helped to identify the Crown Colony government as an authority and therefore the early introduction of the jury system is less surprising.

22 Jury Ordinance 1841, s 1. These were members of the Legislative Council, Governor appointees, judges, ministerial officers of the courts coroners, gaolers, constables officers of the navy and army on full pay, clergymen, priests, and ministers of religion, barristers and solicitors actually practising, physicians, surgeons and apothecaries, revenue officers pilots, masters of vessels employed in the service of the government.

23 Jury Ordinance 1841, s 2.

24 Jury Ordinance 1841, s 1 disqualified those convicted of treason, felony or perjury.

25 Jury Ordinance 1841, s 2 alphabetical order and s 6 general order.

26 Jury Ordinance 1841, ss 10-12. This is in contrast to New South Wales which used military placement for juries for many years after their early legislation.

27 Jury Ordinance 1841, s 12.

28 Jury Ordinance 1841, s 9.

29 Introduction to English Legal History above n 7, 416.

30 A H McLintock Crown Colony Government in New Zealand (R E Owen, Government Printer, Wellington, 1958) 77. 


\section{Special Juries}

The Special Jury was introduced to the colony in $1844 .{ }^{31}$ The initial legislation did not state what purpose the special jury would serve. However, from English practice it was clear that this institution was to judge issues of a more technical nature. ${ }^{32}$ Later legislation spelt out that this institution would involve men of the "best condition" to judge issues that were out of the contemplation of "ordinary" men. ${ }^{33}$ However, this legislation recognised the infancy of the colony and did not purport to give guidelines on how to distinguish men for the purposes of special jury selection. Indeed the range of people in New Zealand's population was large, and therefore distinctions between the merits of various occupations would have been extremely difficult. This, and provisions on grand juries, were to become the subject of vigorous debate in later years as it seemed to many that the section made provision for matters of higher financial concern to be dealt with in a manner different from everyday issues. 34

\section{Grand Juries}

Unlike the special jury, the grand jury was not specifically introduced into legislation until 1868. ${ }^{35}$ However, it is clear that grand juries were in operation well before that time. ${ }^{36}$ Early legislation shows recognition of the functions of the grand jury but a reluctance to introduce it. For example, the Supreme Court Ordinance of 1841 had provision for indictments to be brought before the court on behalf of the Attorney-General or Crown

31 It is also interesting to note that the initial Ordinance had provision for its own repeal by 1843 Jury Ordinance 1841, s 15. This would support the proposition that the Colonial Office felt a strong need to continue control of the Colony. By positing the need for repeal within the legislation, the Colonial Office could ensure a check on the Colony was maintained. However, the 1841 Ordinance was not repealed until the Jury Amendment Ordinance of 1844. Similarly, the title of the 1844 Ordinance declared that it was for the "temporary" provision for juries. That this was meant to raise uncertainty over the continuation of the provision for juries is unlikely and could simply have been intended to ensure a check on the system.

31 Jury Amendment Ordinance 1844, s 6. See also Supreme Court Rules 1844, rule 74.

32 This was certainly the purpose it came to serve, Jury Act 1898, s 3. See the section on special juries later in this paper.

33 Jury Act 1868, s 14.

34 "Joint Statutes Revision Committee: Juries Act Amendment Bill" Legislative Council (No 3) 1898, 1,1-4. [L C No3]. This will be discussed at greater length later in the paper.

35 Juries Act 1868, s 17.

36 Memorandum of the Judges Assembled in Conference at Auckland, Respecting the Jury System [1861] AJHR D-2A [Judge Memo AJHR]. The judges involved in this memorandum note the lack of provision for guidelines for grand juries. See also The British Commonwealth above n 1, 95. 
Prosecutor "as if [they] had been presented by a grand jury" ${ }^{37}$ However, this reluctance was quickly overcome and although there was no specific provision for the grand jury, the section usurping its role was omitted in $1844 .{ }^{38}$ Therefore, its use was clearly envisaged ${ }^{39}$ and it was certainly utilised during this time. ${ }^{40}$

\section{B Adaptation to New Zealand Circumstances}

\section{Adaptation of the Property Qualification}

After the initial transfer of British legislation to New Zealand, it quickly became clear that any reform of the legislation needed to take New Zealand's specific circumstances into account. This included not only the financial make-up of the colony but also the demographics. Thus the Ordinance in 1844 eliminated the property qualification for jury membership in recognition that land titles were not sufficiently advanced to warrant their use as a defining characteristic in legislation. Instead, a qualification of "good fame and character" was inserted. ${ }^{41}$

Recognition that the Maori of New Zealand significantly outnumbered the colonisers was also included in this legislation. The qualification section was extended to allow Maori in mixed juries if their "capability may be certified" for the trial of cases where the property or person of any Maori was affected. ${ }^{42}$ By incorporating Maori into the jury system in this way, a degree of legal separatism began to emerge. ${ }^{43}$ However, the very fact that Maori as an indigenous people were incorporated at all shows the respect they were granted by the British Government. $^{44}$

37 Supreme Court Ordinance 1841, s 20.

38 Supreme Court Ordinance 1844.

39 This is Jim Cameron's assertion: The British Commonwealth above n 2, 95. However, the evidence from the inclusion and omission of the section concerning indictments certainly indicates that his assertion is right. Similarly, the commentary from the judges of 1861 shows that the grand jury was being used at least by the early 1860s.

40 Judge Memo AJHR above n 36.

41 Jury Amendment Ordinance 1844, s 1.

42 Jury Amendment Ordinance 1844, s 1. Just what "capability" required is unclear, although it may have been a reference to the need to speak English.

43 Maori were placed in the same category as aliens for the purposes of jury formation, Jury Act 1868.

44 M P K Sorrenson in Oxford History above n 2, 141, 142. 


\section{Early Maori and the Jury System}

There was dispute over whether Maori rights should be governed by the same legal system as Europeans. ${ }^{45}$ In theory English law prevailed, but in practice it was recognised as impotent, not only because of the limited resources of enforcers but also because few Maori could comprehend or understand the English language and laws. ${ }^{46}$ Therefore, even with the provision for mixed juries, it seems fair to assume that most Maori had little or no contact with this institution in its early stage. ${ }^{47}$

Indeed other legislation which was introduced in this period seems to lead to the conclusion that it was expected Maori would use the provision for a mixed jury infrequently. In 1844 Governor FitzRoy introduced the Native Exemption Ordinance which stated that Maori were to be controlled by a combination of European and Maori law. ${ }^{48}$ This worked well for Maori as it maintained their traditional hierarchy but many settlers were opposed to it as it seemed to be a token of appeasement to Maori. ${ }^{49}$

Further provision for dealing with cross-cultural offending was provided by the Resident Magistrates Courts Ordinance of 1846. This effectively gave the Resident Magistrate power over all criminal cases of a summary nature between two Maori. ${ }^{50}$ The provisions also allowed Resident Magistrates to deal with civil summary disputes between Maori and Pakeha. ${ }^{51}$ In addition it recognised the intricacies of the British judicial system and to that end set up arbitration courts to settle civil disputes between Maori. ${ }^{52}$ The Ordinance even allowed for Maori to arbitrate amongst themselves. ${ }^{53}$ Given the contempt

45 M P K Sorrenson in Oxford History above n 2, 141, 149.

46 M P K Sorrenson in Oxford History above n 2, 141, 149.

47 Jury Amendment Ordinance 1844, s 1.

48 The Native Exemption Ordinance 1844, s 3 required that Magistrates issue warrants through Maori chiefs, and allowed offenders to avoid sentence by paying compensation to the defendant; s 9. By using the chiefs as intermediaries, the magistrates could enforce law in a culturally acceptable manner. Similarly, using the process of compensation for retribution instead of incarceration or other deterrence practices was closer to Maori practices of utu and therefore also more acceptable to most Maori. See generally Oxford History above n 2149.

49 M P K Sorrenson in Oxford History above n 2, 141, 149.

Resident Magistrates Court Ordinance 1846, ss 7-11.

51 Resident Magistrates Court Ordinance 1846, ss 12-18.

52 Resident Magistrates Court Ordinance 1846, s 19.

53 Resident Magistrates Court Ordinance 1846, s 20. Only when the two Maori arbitrators failed to agree did the Resident Magistrate intervene, s 22. 
with which the British had treated other indigenous cultures, especially the aborigines of Australia, these inclusive provisions are remarkable in a colonial context. ${ }^{54}$

However, recognition of the complications of the European legal system seems to have been regarded as immaterial when there was a criminal dispute between Maori and European. ${ }^{55}$ In these cases Maori were tried under European law using European mechanisms including the jury. ${ }^{56}$ Therefore, while there was provision for Maori involvement as jurors at this early stage in New Zealand's legal history, it seems likely that Maori accused were intended to use the alternatives made available or to be tried by Europeans.

\section{GROWTH AND EXPEDIENCY $1852-1890$}

By the 1850s it became clear that continued control from England was impossible because of the delays and distance between the two countries. Therefore, with the 1852 Constitution Act, New Zealand became a self-governing colony. This had implications for all aspects of the New Zealand judicial system and the jury system was no exception.

With the birth of domestic government, local needs could be addressed more rapidly and precisely than previously. These needs included the progression of colonisation quickly and efficiently. Moreover, the New Zealand population was rising rapidly and it became necessary to increase the checks on New Zealand's new society. To this end, jury legislation attempted to incorporate both the need for more speed in trial proceedings and an increase in regulation.

\section{A The Struggle for Increased Efficiency}

The first action towards increasing efficiency in the jury system was to reduce the numbers of jurors needed to try a case in less serious circumstances. ${ }^{57}$ This came with the Supreme Court Amendment Act of 1862 which established minor juries consisting of only

54 M P K Sorrenson in Oxford History above n 2, 141, 142.

55 There is no provision for this situation in the Resident Magistrates Court Ordinance 1846 and it must therefore be presumed that Maori were tried under the European system. This is certainly what the provision for mixed juries in cases where Maori were involved would indicate, Jury Amendment Ordinance, s 1.

56 However, the tone of these sections was entirely patriarchal. Therefore, it may have been that the Resident Magistrate could have utilised his powers over the natives and been given scope to intervene on their behalf.

57 Supreme Court Amendment Act 1862, s 8. The classes of case that could be tried by minor jury included mainly issues of fact and disputes of less than 100 pounds. 
six people. ${ }^{58}$ The same procedure applied as for petty juries, the only difference being that the judge could decide whether to call twelve or six jurors. ${ }^{59}$ A similar provision was established for special juries that reduced the number of jurors in civil cases to four. ${ }^{60}$

The pressure on juries to deliver a verdict quickly began to increase. This is reflected in an 1868 provision which stated that if the jury did not return a verdict within 12 hours they would be discharged, and a new trial ordered. ${ }^{61}$ A potential mechanism to ensure jury efficiency was the discretionary provision of refreshment and heating. ${ }^{62}$ Castles notes that in Australia this was used as a tool to ensure a quick verdict from the jury or to turn around a dissenting vote. ${ }^{63}$ However, there is no evidence that this provision was ever used for that purpose in New Zealand.

Any fears that judicial discretion controlled the verdicts of early juries are probably unfounded because although a unanimous verdict was always preferred, the pressure to achieve unanimity was diminished in 1876 when provision for a three-quarters majority was introduced. ${ }^{64}$ In itself the provision for a three-quarters majority was another mechanism for speeding up the trial process as it ensured that verdicts could be passed with far less debate.

Lastly, a provision was introduced to allow juries to hear more than one issue at the same sitting. This had been standard practice in England for decades, at least in the

58 Supreme Court Amendment Act 1862, s 7. This would logically have been intended to reduce to amount of time the jury would spend in deliberations.

59 Supreme Court Amendment Act 1862, s 13.

60 Jury Amendment Act 1878, s 8. But unlike the provision for minor juries both the participants and the Supreme Court had to agree on the juries' reduction. An interesting but obviously essential provision within the four-member special jury was that this jury had to be unanimous. Jury Amendment Act 1878, s 12. This was in contrast with provisions since 1876 for other juries who could pass judgement with a three quarter majority. Juries Act 1876, s 7.

61 Jury Act 1868, s 53. This provision for 12 hours was later replaced by "for such a period as the judge thinks reasonable not being less than four hours." Juries Act 1880, s 157. While the time taken to conduct a retrial would probably have been longer than simply waiting for the original verdict, the threat of discharge may have stirred some jurors to ensure a quick verdict. This seems to have been the intention of the legislation although how it worked is unclear. In fact it may have had a negative effect, as some jurors would have relished the idea of an early discharge.

62 Juries Act Amendment Act 1876, s 6.

63 An Australian Legal History above n 14, 272.

64 Jury Amendment Act 1876, s 7. The three quarters majority was taken as a verdict if there had already been three hours of discussion, three quarters of the jury had intimated to the judge that they have agreed, and there seemed no possibility of a unanimous verdict being reached. 
eighteenth century, but was only introduced in New Zealand legislation in $1868 .{ }^{65}$ The introduction of this practice in England has been attributed to the lack of concern about the trial process, or more simply, that the practice happened by default. ${ }^{66}$ However, a variety of factors point to the opposite reason for the introduction of the New Zealand provision. Unlike England, the practice in New Zealand was legislatively introduced along with a spate of provisions intended to speed up the trial process. ${ }^{67}$ The fact that it was in legislation at all seems to indicate that it was a deliberate attempt at efficiency rather than a practice merely stemming from any lack of care. Similarly, the New Zealand practice was subject to party approval ${ }^{68}$ and was therefore more regulated than the English practice appears to have been.

\section{B Increased Regulation}

Another theme that characterised this period is the increased emphasis on regulation. Prior to the 1860s, jury legislation, in common with New Zealand's legislation in general, was very simple. The judiciary noted this lack of detail as early as $1861{ }^{69}$ However, a striking aspect of the jury legislation from the 1860s onwards is the increase in the number and length these of sections. Similarly, a great number of these sections were created specifically for the organisation of procedure. ${ }^{70}$ Issues that would once have been left to the discretion of the sheriff were now the subject of exacting regulations, including the shape and colour of the jury boxes! ${ }^{71}$

The seriousness with which this legislation regarded the trial process is no doubt a reflection of the government's growing sophistication. The existence of the parliamentary system meant that legislation was not only more relevant to the current New Zealand

65 This began with the Juries Act 1868, s 38. As this practice had been around for some time in England it is feasible that it was in use in New Zealand earlier than 1868, however there are no records that indicate this.

66 Introduction to English Legal History above n 7, 417.

67 As has been previously noted.

68 Juries Act 1868, s 38.

69 They complained of the lack of instruction over the forming of grand and special juries and also the apparent lack of consideration of the implications for jurors. Judge Memo AJHR above n 36 . No doubt in response to these calls but also within its growing constitutional framework, the legislature mentioned the existence of the grand jury in legislation for the first time, Jury Amendment Act 1868, s 17.

70 An interesting illustration of this is the consolidating legislation passed in 1868 . Where previous legislation had noted the procedure by which juries could be selected, this Act went as far as to note the exact procedure for the selection process, Jury Act 1868, ss 9-16.

71 The boxes where names were placed for the balloting process. Jury Act 1868, s 13. 
circumstances, but also that more attention could be paid to detail. The increased attention to detail made later statutes more lengthy and complex, but the overall format is clearer and consequently legislation became more accessible. ${ }^{72}$

Another characteristic of jury legislation in this period was the continual change in the criteria for exemption. Persons who were exempted initially were the same as those in the British legislation and were restricted to men in official occupations especially in government service. ${ }^{73}$ During this period there was an increase in the importance given to these and other civil servants and the list of people exempt became very lengthy. ${ }^{74}$ The increase in the legislative detail and enforcement of jury service with fines shows that the process was taken seriously. ${ }^{75}$ However, this large number of exemptions illustrates that jury service was seen as a task and a duty rather than a right or privilege to preside over other citizens' fate.

\section{New Zealand - The Fastest Legislator in the West}

As New Zealand increased its sophistication, it also increased the volume of legislation. Between 1840 and 1860 for example there were few statutes concerning juries. Yet between 1860 and 1880 there were at least thirteen. ${ }^{76}$ This is perhaps due to the infancy of the colony. However, even then the New Zealand government seemed to illustrate the tendency to pass generous amounts of legislation, which Palmer attributes to the New Zealand government in general. ${ }^{77}$

This had specific implications for the jury system because it meant that many of the changes came individually rather than in a neatly consolidated statute. Indeed, many of the most far reaching reforms of this and other periods were passed into law in

72 In the consolidating Act of 1880 for example, there is a notable increase in the structuring and clarity within the statute, Juries Act 1880.

73 The Jury Ordinance 1841, s 1.

74 Volunteer Act 1865, s 26 exempted volunteer firemen from jury service. While this was partially repealed in 1866 in the Volunteer Amendment Act, s 3, the provision for exemption for active fire fighters remained and was affirmed in the Jury Amendment Act 1874, s 2. Similarly, all Railway workers earned an exemption in this period

75 Fines were a part of the jury system from its conception, there being fines for non-appearance as early as the 1841 Ordinance, s 17.

76 Refer Appendix.

77 Geoffrey Palmer Unbridled Power (2 ed, Oxford University Press, Auckland, 1987) 140. 
amendment Acts whose short title belied the significance of the legislation for the jury. ${ }^{78}$ Notwithstanding any problems this creates for contemporary research, this piecemeal approach to the law of juries must have made it very difficult for citizens to gain access to the law. ${ }^{79}$ Moreover, while it is clear that the jury was regarded as fundamental in theory, this practice raises questions as to how much significance it was given in practice. ${ }^{79}$

\section{THE STATUS QUO 1890-1940}

In contrast to the exploration of new legislative avenues in previous periods, the period from 1890 to 1940 was characterised by lack of change. ${ }^{80}$ Indeed, because of the style of legislating on jury matters, the period between 1890 and the early 1900s could easily be overlooked. However, while there was little legislative change, the end of this period marks the beginning of increasing debate over issues that would later become the subject of reform.

\section{A Peremptory Challenge}

One topic of debate that did result in legislative change in this period was the equal access to the challenge process. The right to challenge members of the jury to ensure that certain persons are excluded from deciding the fate of the defendant has been and still is a principle at the heart of the New Zealand jury system. Similarly, the argument that this process is in fact used not to keep unqualified people off, but rather to ensure that people favourable to the challenger's case are selected has existed for many years. ${ }^{81}$

Prior to 1898, this judicial principle was extended only to defence counsel and the Crown had no free right to challenge. ${ }^{82}$ A Bill proposing (amongst other things) that the numbers of challenges should be reduced and that the right itself should be extended to

78 For example, the provision for reducing the number of jurors was passed in the Supreme Court Amendment Act 1862, s 7. Similarly, the change from a unanimous verdict to a three-quarters majority was passed in an amending statute, Jury Amendment Act 1876, s 7, and the provision for Grand Juries was not passed until 1868 although they had clearly been operative for some time.

79 This seems to have been a common trend throughout the legislative history of New Zealand. Indeed it could be argued to still exist today.

80 Change did occur of course, things were altered and added, but most of these were only minor aspects of the law such as increasing or decreasing the exemption qualifications and the issues of peremptory challenge.

81 Note for example the quotations from judges in 1898 over the use of the peremptory challenge. LC No 3 above n 34, 1-4. Many Maori and women's commentators in later years also noted the efficiency of the challenge process in keeping these groups off juries. This is discussed at more length later in this paper.

82 The Crown had a limited right to challenge for cause certain. Juries Act 1868, s 42 and Juries Act 1880, s 123. 
the Crown prompted debate both within parliamentary circles and in the judiciary. ${ }^{83}$ Judicial debate virtually ignored this lack of equal access to the challenge process and centred instead on reducing numbers. ${ }^{84}$ The legislature noted that the provision for Crown counsel to ask jurors to stand aside equated to an equal if not better right to challenge than was held by defence counsel. ${ }^{85}$ However, it seems to have been eventually accepted that there was an unequal distribution of power as the Bill promoted the inclusion of the right to challenge equally and it was passed into legislation. ${ }^{86}$

\section{THE STRUGGLE FOR EQUALITY}

The reaction to jury legislation after the 1900's is neatly in contrast to the apparent apathy of the earlier period. While many of the issues, especially grand and special juries, had been raised earlier, this was the period for the actual reform of the system in a variety of areas. It is suggested that this was so because the jury system no longer followed the development of society generally.

Educational qualifications were now the norm and occupational hierarchies less so than in the nineteenth century. Provision for grand and special juries had become outdated in the eyes of many. Similarly, Maori were becoming increasingly urbanised and assimilated into European institutions, and the provision for all-Maori juries was also seen by many as unnecessary. Lastly, women had held the right to vote since 1893 and yet were still excluded from jury service.

Therefore the 1900s brought a level of controversy to the development of the jury system that had not before been seen in New Zealand. It concerned three key topics that centred on the struggle for equality within the jury system.

83 LC No 3 above n 34, 1-4.

84 LC No 3 above n 34, 1-4. Only one out of the five judges of the Supreme Court saw fit to mention the issue of Crown's challenge at all. Pennefather J noted that the dangers of politicisation within the jury system warrant the retention of the challenge process in its present form. He noted that the Crown should have the right to challenge for the same reason. The judiciary also unanimously concluded that the challenge mechanism was being abused as it was primarily used to get favourable people onto the jury. This debate proved to be fruitful and the numbers of challenges available was reduced from twelve to six, Juries Act Amendment Act 1898, s 11.

85 It was noted in the Parliamentary Debates that provision had already been made for the Crown to order jurors to stand aside in criminal cases. It was argued that provision to reduce the number of challenges available to defence counsel would reduce the prisoner's rights even further, (19 October 1898) 105 NZPD 180. 


\section{A Grand Juries}

There was continual debate over the use and particularly the membership of the grand and special juries. This indicates that there was dissatisfaction with the jury system's consistency with social development. However, any dissatisfaction seems to have been forgotten or resolved for some periods as the institution of the grand jury remained for many decades. It is suggested that this was allowed to continue because of the desires and status of the "majority" over which the judiciary held much sway, coupled with relative public indifference.

The 1898 Bill that was concerned with peremptory challenge prompted debate about the desirability or otherwise of the grand and special juries. However, unlike the issue of peremptory challenge, this debate had arisen with just as much vigour in previous years. ${ }^{87}$

The original purpose of the grand jury both in England and in New Zealand was to "search out local crime and to bring offenders before the court". ${ }^{88}$ However, this purpose never had the same emphasis in New Zealand and was abandoned in $1893 .{ }^{89}$ Instead, the purpose of the grand jury both in New Zealand and England became similar to the preliminary hearing process of today which decides whether there is a prima facie case. ${ }^{90}$

It appears that a Supreme Court judge would describe a list of cases to the grand jury for their consideration. ${ }^{91}$ If the grand jury returned a verdict of a true bill for a particular case it would then go immediately to the waiting petty jury. ${ }^{92}$ Each case would be considered and referred to the petty jury individually. ${ }^{93}$ But by about the 1920s this referral was virtually automatic. ${ }^{94}$ An interesting practice in the South Island was for the

87 There is even note of the need to abolish it as early as 1870. (9 August 1870) 8 NZPD 376-378. Indeed one politician noted in 1883 that the issue of grand juries had been "raised over and over again as long as he could remember." (1 August 1883) 45 NZPD 245. Although there is little record apart from the brief mention in the 1870 Debates, of debate on the grand jury before 1883 .

88 The British Commonwealth above n 1, 95.

89 Criminal Code Act 1893, s 385.

90 (9 August 1870) 8 NZPD 377-378.

91 There is no written record of how this institution functioned in practice, therefore anecdotal evidence from George Barton has formed the basis of this section. This was gathered in a personal conversation on the 19 August 1998. [Anecdotal evidence]

92 Anecdotal evidence above $\mathrm{n} 91$.

93 Anecdotal evidence above $\mathrm{n} 91$.

94 Anecdotal evidence above $\mathrm{n}$ 91. Indeed, the function of the Grand Jury as a rubber stamp was recognised by enacting legislation that allowed judges to review depositions and judicial discretion to dismiss the indictment. Crimes Act 1954, s 42 (3), (4), (6). 
grand jury to present the judge with a pair of white gloves if there were no criminal cases to be considered. ${ }^{95}$ Judges often used this opportunity to speak in general terms on law, order and morality or even the state of the nation. ${ }^{96}$

In 1883, a Private Members Bill was introduced by J A Tole. This included a measure to abolish the grand jury. The Bill generated an immense amount of support in the House of Representatives. ${ }^{97}$ However, it seems that the Legislative Council must have opposed this Bill because the grand jury remained until $1961 .{ }^{98}$

\section{Parliamentary Debate}

Mr Tole took particular note of the discrepancies in the selection process of the grand jury. ${ }^{99}$ He claimed that the occupation distinctions on which it was based in England were not founded and almost farcical in New Zealand. ${ }^{100}$ He also argued that the grand jury was merely checking the information of a Magistrate or Justice of the Peace. ${ }^{101}$ The very nature of the grand jury was that it was composed of people subject to the opinions and pressure of topical news. Therefore he argued this check was open to politicisation by protecting criminals of current political favour or condemning innocent men who had none. ${ }^{102}$ He proposed New Zealand revert back to the system established in 1841 of a single signatory for indictments, and cited the successful use of this practice in Scotland and parts of Australia. ${ }^{103}$ Importantly, it was noted that the District Court had been operating without grand juries for years and had instead been successfully using a Crown Solicitor for the indictment process. ${ }^{104}$

95 Anecdotal evidence above $\mathrm{n} 91$.

96 Anecdotal evidence above $\mathrm{n} 91$.

97 The Minister of Justice was opposed to the Bill but the other seven commentators approved and there is no record of any persuasive arguments for the retention of the grand jury in this year, $(1$ August 1883) 45 NZPD 242. Indeed, there is a reference to a first reading in the Legislative Council but no other record of debate on the Bill or the topic of Juries exists in this year. (1 August 1883) 45 NZPD 343.

98 It was perhaps through luck rather than a loyal following that this institution remained at all because as the debates show there was little support for the Grand jury at least in 1883.

99 Jury Act 1868, s 14 provided that men for the special and grand juries should be in general "men of the best character".

100 (1 August 1883) 45 NZPD 242-243.

101 (1 August 1883) 45 NZPD 243.

102 (1 August 1883) 45 NZPD 243.

103 (1 August 1883) 45 NZPD 243.

104 (1 August 1883) 45 NZPD 244. 
When the issue arose again in 1898, the parliamentary arguments against the grand jury were very similar. ${ }^{105}$ However this time the division of opinion and the arguments for its retention were recorded. It was noted that the function of the grand jury was to save innocent men from the indignity of a formal trial. ${ }^{106}$ Similarly, it was argued that replacement of the grand jury with a single representative was far more open to corruption and politicisation. ${ }^{107}$ It was also seen by some as a mechanism to allow citizens to express their own views of justice. ${ }^{108}$

\section{Judicial Debate}

In judicial debate, opinions were also clearly divided. Arguments for the retention of grand juries were based on the fact that they did not cost a great deal, were serving their purpose with accuracy and reliability and that they performed a necessary function. ${ }^{109}$ The possible politicisation of the indictment procedure was again raised but this time with a comparison of overseas experiences. ${ }^{110}$

The arguments for abolition were also very similar to those already proposed and included concepts of increased cost and a lack of efficiency. However none of the arguments managed to sway the legislature. Even though the English grand jury was abolished in 1933, New Zealand maintained the institution until 1961. ${ }^{111}$

105 (19 October 1898) 105 NZPD 179-188. Particularly arguments such as the redundancy of this institution in present conditions, the cost of maintaining it, overseas precedent and the fact that the District Court had been operating successfully without a grand jury system for many years.

106 (19 October 1898) 105 NZPD 186. Some members saw this alone as so important that they thought by itself, it justified the retention of the institution.

107 (19 October 1898) 105 NZPD 181 and 185; (8 July 1898) 101 NZPD 322.

108 The British Commonwealth above n 1, 96.

109 LC No 3 above n 34, 1-4 per Prendergast CJ, Edwards J and Pennefather J.

110 LC No 3 above n 34, 4. Pennefather J notes that although it inevitable that innocent men will sometimes be "exposed to the indignity of a public trial" the institution of the grand jury reduces this evil by ensuring that there must be at least a prima facie case against the accused. He bases his arguments on his experiences in South Australia were there was no provision for grand juries.

111 Administration of Justice (Miscellaneous Provisions) Act (UK) 1933, ss 1-3. However, while s 1 abolished grand juries outright, s 4 provided for their continuation in London and Middlesex certain circumstances. (See the First Schedule.) Castles posits that the grand jury was abolished in South Australia as early as 1852 An Australian Legal History above n 14, 322. However, in NSW, the legislation is somewhat ambiguous as to whether grand juries were replaced by a commissioner or in fact continued: Jury Laws Consolidation Act 1851 (NSW) 15 Vic No3, ss 9-11. The New Zealand grand jury was abolished by the Crimes Act 1961, s 345 . 


\section{B Special Juries}

After their introduction in 1844, special jury trials seem to have become widely accepted as a vital part of judicial practice. ${ }^{112}$ They were largely unregulated, as there were no legislative guidelines on either composition or the constitution of this institution, these being left to the discretion of the Supreme Court. ${ }^{113}$ The judges of this court noted the lack of precise provision for both grand and special juries in $1861 .{ }^{114}$ But although both the special and grand jury composition became regulated soon after by legislation in $1868,{ }^{115}$ there was not a limitation of the classes of cases to be considered by special juries until 1898. ${ }^{116}$ Even after this provision there remained a significant discretionary judicial power as the section required consent from all the parties or the judge. ${ }^{117}$

As there was little legislative stipulation of the purpose of this institution and little record of its use, it is difficult to assess how it worked in practice. However, some assumptions can be made. It seems clear that it was based on the principle that like persons should be treated alike.118 This was prefaced by the condition that a "like" person should be restricted to one of the "best condition". ${ }^{119}$ This prerequisite ensured that the cases dealt with by special juries contained matters (or at least people) which were of some financial importance.

The function of the special jury was to establish which material facts had been proved. While this appeared to be the same function as the petty jury, the premise of the distinction seems to be that mercantile and business facts needed to be considered in a different manner to those of common disputes. ${ }^{120}$ Indeed, the rarity of special juries in criminal cases seems to reinforce the presumption that it was the mercantile nature of proceedings that warranted special treatment. ${ }^{121}$

112 This conclusion can be derived from the wide amount of support for this institution in Parliamentary debates in later years.

113 Jury Amendment Ordinance 1844, s 6.

114 Judge Memo AJHR above n 3.

115 Jury Act 1868, grand juries, s 17, special juries, s 14.

116 Juries Act 1898, s 3.

117 Juries Act 1898, s 3.

118 (8 July 1898) 101 NZPD 317.

119 Jury Act 1868, s 14.

120 Because the issues involved were "complicated and technical questions..." JE Denniston, L C No3 above $n 34,3$.

121 L C No3 above n 34, 2 per Edward Connoly CJ. 


\section{Parliamentary Debate}

Before the legislation in 1898, the same debate that was raised for grand juries was raised over whether the special jury should continue to exist. One of the biggest criticisms of the special jury was that it was based on the false premise that its members were of a higher class and intelligence. ${ }^{122}$ It seems clear that in New Zealand however, members of the special jury list did not have any significantly greater intelligence than members of the common jury. ${ }^{123}$ Moreover, it was argued that unlike Britain, where this system originated, New Zealand did not have an existing class system that included an leisured educated class. ${ }^{124}$ Indeed it was argued that there was no class system on which to make a true distinction. ${ }^{125}$

It was accepted that the special jury could provide a panel of experts well equipped to deal with the intricacies of mercantile cases. ${ }^{126}$ However, the fact remained that jurors were selected not because of any expertise on the issue to be tried, but first by their standing in the community and then by lot. This form of selection ensured that in fact, the jury was not certain to contain any person with expertise in the required area. ${ }^{127}$

\section{Judicial Debate}

Members of the judiciary were perhaps the strongest advocates for the continuation of the special jury. ${ }^{128}$ This is not surprising because they were of the "class" which was defined as essential for special and grand jury membership.

Within the judiciary however, there was a distinction made between the use of the special jury in civil and criminal cases. In the latter, there was a general consensus that the abolition of the special jury would be of no significance because it was used so rarely. ${ }^{129} \mathrm{In}$

122 (8 July 1898) 101 NZPD 317.

123 (1 August 1883) 45 NZPD 242. Indeed it was noted that eighty percent of the New Zealand population could read or write which certainly needed a "considerable amount of intelligence..." (7 July 1898) 101 NZPD 317.

124 (1 August 1883) 45 NZPD 242.

125 (1 August 1883) 45 NZPD 242.

126 (8 July 1898) 101 NZPD 320.

127 (8 July 1898) 101 NZPD 317.

128 LC No 3 above n 34, 1-4.

129 LC No3 above n 34, 1-4. Although Prendergast CJ is an exception in this regard. He was of the opinion that the law could not be adequately altered in the case of criminal trials to warrant the abolition of the special jury. While the other four judges do not comment on the effectiveness or otherwise of the special jury in criminal cases they do not oppose its abolition because, as stated, it was used very rarely. 
the former however, the need to maintain the special jury was unanimously accepted. ${ }^{130}$ It was posited that this "class" of jury was well informed, well educated and therefore in a "better position to understand complicated and technical questions and to appreciate the legal principles to be applied to them". ${ }^{131}$ Judges regarded arguments that wealthy suitors gained an advantage from the special jury as unfounded because both parties would get the benefit of the better tribunal. ${ }^{132}$ These arguments seem to have won out at this time because the 1898 Bill was altered to provide for regulation of the special jury rather than its abolition. 133

Recognition of New Zealand's social conditions was eventually given in the 1930s and the membership requirements were changed to take account of the lack of occupational hierarchy in New Zealand. ${ }^{134}$ Once these were gone, debate stopped and both the grand and special juries declined into disuse fairly rapidly. They were eventually abolished in 1961 and 1981 respectively, with little debate. ${ }^{135}$

\section{Maori Juries}

Provision for Maori involvement in the jury trial process was made very early in New Zealand's history. ${ }^{136}$ However it was soon realised that differences in language and culture warranted a separate provision and all-Maori juries were introduced. The provision for allMaori juries remained uncontroversial from its conception in 1862 until the beginning of its demise in 1961. It is arguable that the provision had been inconsistent with public opinion for many years. But it was only when it became a topic of debate that its eradication was an issue. ${ }^{137}$

The Juries Amendment Ordinance of 1844 made provision for Maori to serve on mixed juries for trials in which the property or person of another Maori was involved. ${ }^{138}$ This

130 LC No3 above n 34, 1-4.

131 LC No3 above $\mathrm{n} 34,2$ per Denniston $\mathrm{J}$.

132 LC No 3 above n 34, 2 per Denniston J.

133 Juries Act 1898, s 3.

134 The Qualification Provisions were changed a number of times but the most significant changes were in 1936 and 1939. Statutes Amendment Act 1936, s 40(4); Statutes Amendment Act 1939, s 37.

135 Crimes Act 1961, s 345 (grand juries) Juries Act 1981, s 4 (special juries) This section repealed special juries by the lack of their inclusion in this consolidating legislation.

136 Jury Amendment Ordinance 1844, s 1. The basis for inclusion on the list was "certified capacity" in accordance with legislation.

137 (28 September 1961) 328 NZPD 2573.

138 Jury Amendment Ordinance 1844, s 1. 
provision was formed in the same way as provisions for Europeans, and Maori still had to fulfil the good character qualifications to be eligible to sit on the jury. ${ }^{139}$ Because of the language barrier it is more likely that Maori made use of the arbitration process set up under the Resident Magistrates Ordinance as this had provision for Maori to adjudicate over Maori. ${ }^{140}$ There is little record of the practice of this period and therefore it is unknown if this section concerning mixed juries was utilised.

There is likewise no record of Maori opinion on the operation of this provision but it was to be short-lived in any case. In 1862 the law was changed again to include a provision for an all-Maori jury and the limitation of the mixed jury. ${ }^{141}$ This was against the wishes of the judiciary who advocated mixed juries only. ${ }^{142}$ In civil cases this section maintained the provision for mixed juries upon the inclusion and request of a Maori party. ${ }^{143}$ It also added a provision in both civil and criminal cases for an all-Maori jury where all parties were Maori. ${ }^{144}$ However if there was a criminal offence between a Maori and a European (regardless of who was the victim and who was the offender), there was no Maori provision and the case would be tried before a European jury. Similarly, where there was a European involved, the Maori party had to request a mixed jury in civil cases. ${ }^{145}$ Unlike the 1844 provision therefore, there was little provision for any Maori to be on the jury where there was a European involved.

Although the implications of this piece of legislation were far reaching, there was no debate on the matter and the Act passed into law quietly. This new "right" to an all-Maori jury was undoubtedly an important one and was of great concern to Maori as later opposition to its repeal would show. However, Cameron suggests that the removal of the right to a mixed jury was more of a disadvantage than the addition of access to an allMaori jury. ${ }^{146}$

139 Jury Amendment Ordinance 1844, s 1.

140 Resident Magistrates Court Ordinance 1846. See the section on Early Maori in this paper for further discussion on this provision.

141 Jury Law Amendment Act 1862, ss 8-12.

142 Judge Memo AJHR above n 36, The judges of the Supreme Court proposed that "natives" should have the option to elect trial by mixed jury which they recommended be made up of six Europeans and six Maori with a right of challenge of three peoples from each race.

143 Jury Law Amendment Act 1862, s 11.

144 Jury Law Amendment Act 1862, s 9.

145 Jury Law Amendment Act 1862, s 11.

146 The British Commonwealth above $\mathrm{n} 1,94$. Although it should be noted that these statements were made in the context of the "integration policy" of the 1960s. 
This stems from the fact that in practice the all-Maori jury was hardly ever used. Initially, this may have been because of the geographically isolated position of many Maori. ${ }^{147}$ However, the rapid urbanisation and integration of later years did little to increase the use of this institution. ${ }^{148}$ Moreover, in cases where it would seem logical to grant the use of the all-Maori jury it was deemed to be unavailable. ${ }^{149}$ The availability of the all-Maori jury was therefore precarious at best and was very infrequently used during its time on the statute book. ${ }^{150}$

The possibility of a sympathetic Maori vote in the jury may therefore have been more advantageous to many Maori in the long run, but the legislation took away that possibility in criminal cases. ${ }^{151}$ Cameron notes that while this may have been a disadvantage for Maori there is no proof that it caused any injustice as there was no protest on the part of Maori while this provision was active. ${ }^{152}$

\section{Initial Debate - 1961}

Unlike the debate surrounding special, grand, and women's juries, there was no gradual build-up of dissatisfaction about the provision for Maori juries. It would seem fair to propose therefore that in the 1960s the majority of society did not yet support its repeal or at least were apathetic towards the issue. However, when the debate did surface it was continuously noted that this provision had been out of date for some time. The debate was therefore clearly prompted by something other than a growing disparity between

147 Michael King "Between Two Worlds" in Oxford History above n 2, 285, 290.

148 This could in fact have stemmed from the ideology of integration itself as Maori avoided Maori institutions in favour of Pakeha alternatives. See generally, Michael King "Between Two Worlds" in Oxford History above n 2, 285, 294-298.

$149 R v$ Paku [1910] 12 GLR 548. The judge in this case states that the dispute was not one between two Maori within the definition of the section. It was however an action under the Tohunga Suppression Act 1908.

150 A reference is made in the Parliamentary Debates that "for some years way back it [the all-Maori jury] had been used about once a year." (13 July 1961) 326 NZPD 500. Unfortunately there are no records as to the correct usage statistics for the all-Maori jury and it is perhaps better to leave it at the commonly accepted fact that, certainly in later years, it was at best used very infrequently.

151 Peter Williams has commented that his gut reaction is that Maori were more objective in considering Maori cases. Personal Correspondence 22 July 1998.

152 The British Commonwealth above $\mathrm{n} 1,94$. However it is doubtful whether Maori complaints from the general public would have been recorded in official records which are primary source for this period. Moreover, it should be noted that any lack of protest might have stemmed from a general feeling of disenfranchisement within Maori society. There is current concern that Maori are underrepresented in the jury system. New Zealand Law Commission Juries in Criminal Trials: NZLC PP 32 (Part 1, Wellington, 1998) 62-79 [Juries in Criminal Trials]. 
legislative and "majority" views although it is clear that its eventual repeal was due to the latter.

Peter Williams claims that what prompted this debate was the controversial case of $R v$ Rau. ${ }^{153}$ The fact that the timing of this case and the beginning of debate over the Maori provision coincide so closely probably justifies his view. ${ }^{154}$ Indeed, the case was specifically mentioned in the parliamentary debates at this time. ${ }^{155}$ However, it is likely that it was not the Rau case itself that prompted debate but rather that a case involving a Maori jury occurred. Because once the debate was triggered, it became clear that many people saw the repeal of this provision as long overdue. ${ }^{156}$

The first parliamentary proposal for the alteration of the Maori jury provision came in July of $1961 .{ }^{157}$ This was initiated by the then Attorney-General J R Hanan and sparked a series of debates during 1961 and 1962. At this early stage Hanan compared the section to practices in South Africa and Alabama at the time and concluded that the continuation of a separate section for Maori was "racial discrimination in its vilest form."158

Later in 1961 the issue was raised again in a full debate when the Juries Amendment Bill was brought before the House. ${ }^{159}$ It was proposed that the section allowing for an all Maori jury be abolished. Instead jury membership would be decided regardless of ethnicity, the only new qualification being that members were "New Zealanders". 160

153 Peter Williams A Passion for Justice (Sheal Bay Press, Christchurch, 1997) 91.

154 Debates began in July of 1961 and the case was heard on 27 June 1961. The court at first instance found Roy Rau guilty of murder. On appeal, the court quashed the conviction and ordered a retrial. $R v$ Rau (16 August 1961) unreported, Court of Appeal, CA 46/61. The controversy centred on the verdict of not guilty which the all-Maori jury returned in this second trial. (No citation is available for the two trial hearings of this case.)

155 (20 November 1962) 332 NZPD 2763-2764.

156 (28 September 1961) 328 NZPD 2573.

157 (13 July 1961) 326 NZPD 500.

158 (13 July 1961) 326 NZPD 501. These comments clearly stem from the focus on integration policy at this time.

159 (28 September 1961) 328 NZPD 2570

160 (28 September 1961) 328 NZPD 2572. 
It seemed to be generally presumed that this legislation would be passed as dates were already proposed for the beginning of this "equal" provision. ${ }^{161}$

However, some members did question whether there had been adequate consultation with Maori. ${ }^{162}$ In response to these queries both the Attorney-General and the member for Southern Maori assured the House that most Maori were supportive of the move to remove this "discriminatory" provision and replace it with full integration. ${ }^{163}$ Indeed when questioned as to whether any section of the Maori people opposed the proposal, the Honourable Sir Eruera Tirikatene implied that there were none. ${ }^{164}$ The House generally accepted this assurance. ${ }^{165}$

\section{Arguments against Integration}

Maori opinion would however become a dividing issue on this topic. Later in 1961 and certainly in 1962 it became clear that this consultation had not been as thorough and universal as the Ministers had made out. ${ }^{166}$ Advocates of the Bill cited the approval of the Maori Council as indicative of Maori approval generally. ${ }^{167}$ But opponents, chiefly the Maori MPs, 168 noted that the Maori Council was not wholly representative of Maori opinion. ${ }^{169}$

An argument, which has implications for New Zealand's current system, is that the provision for an all-Maori jury may help to reduce the disproportionate numbers of Maori

161 (28 September 1961) 328 NZPD 2572. It was noted that all (male) New Zealanders would be equally liable to serve on juries from 1 December 1962. Until that time that provision was made for Maori to volunteer their names onto the jury lists, as was the case for women. The problems with this provision are considered further in the discussion on women jurors.

162 (28 September 1961) 328 NZPD 2571-2572.

163 (28 September 1961) 328 NZPD 2571.

164 (28 September 1961) 328 NZPD 2572. In fact the member for Southern Maori stated that he had "never met any" Maori who were opposed to the proposal to abolish Maori juries.

165 (28 September 1961) 328 NZPD 2574.

166 (20 November 1962) 332 NZPD 2753 and 2760.

167 See for example, (11 October 1962) 332 NZPD 2009 and 2012; (20 November 1962) 332 NZPD 2756.

168 Contrary to his earlier position, Eruera Tirikatene was one of the leading advocates against the imminent introduction of the Bill, (20 November 1962) 332 NZPD 2762-2765. Mrs Ranata also claimed that not all Maori agreed to the Bill, (20 November 1962) 332 NZPD 2760.

169 (11 October 1962) 332 NZPD 2010. 
inmates in prison. ${ }^{170}$ It was argued that the statistics showed that Maori were imprisoned at a far higher rate than non-Maori and that culturally, the provision for all-Maori juries should be used to reverse this trend. ${ }^{171}$ This would fit with the policy of current bi-cultural justice initiatives, but the fact remains that the provision had failed to have any impact on numbers of Maori offenders during its long existence. ${ }^{172}$

A final argument against the abolition of all Maori juries and integration of Maori generally in the jury system revolved around the challenge mechanism. It was noted that it was very unlikely for any Maori to get on a jury which was considering matters between Maori and European. ${ }^{173}$ This was a concern for Maori especially in criminal cases where personal liberty was at stake. It was feared that Maori would be inadequately represented within the jury system through this process of challenge and the lack of a separate Maori provision. These assertions were quite probably correct at the time and there is concern that they remain today. ${ }^{174}$

\section{Arguments for Integration}

While the key division was between Maori MPs and the government, there were still many arguments over the general implications of the Bill. Not least of these was the continued assertion that having any kind of separate provision based on race was discriminatory. ${ }^{175}$ It was argued that the legislation implied the incompetence of Maori to try cases. ${ }^{176}$ Similarly, it created arguments that Maori did not trust the competence of

170 There is continuing concern about the number of Maori offenders in New Zealand. Many commentators have noted the possibility of utilising tribal hierarchies to try and alleviate this problem. New Zealand Courts Consultative Committee Report of the Courts Consultative Committee on He Whaipaanga Hou (Wellington, 1991) 13-18 and 49-51 Indeed, forms of Marae based justice are in operation currently. Using an all Maori jury in certain cases may still be a viable option in reducing the numbers of Maori offenders as its emphasis on Maoritanga through its membership may prove to be more respected and therefore more suitable.

171 (11 October 1962) 332 NZPD 2013.

172 It should be remembered however that the Maori provisions were used very infrequently. With the increased awareness that Maori are underrepresented within the jury, the introduction of similar provisions today may have a more positive effect.

173 (20 November 1962) 332 NZPD 2754.

174 "Call for more Maori jurors when Maoris are on trial" The Dominion, 18 July 1998, 2.

175 There was discussion at this point about New Zealand's obligations to the United Nations, which advocated that there should be no differentiation based on race notwithstanding its objectives. (20 November 1962) 332 NZPD 2757.

176 (20 November 1962) 332 NZPD 2749. 
European juries. ${ }^{177}$ The presence of Maori on local councils and in Parliament was given as proof of Maori competency ${ }^{178}$ and education statistics clearly showed equal achievement. ${ }^{179}$ It was therefore argued there was no reason for the discrimination.

Members of the Opposition quite rightly took issue with this last justification because while the government was advocating equality at all costs in this debate, it had not followed a similar line in regards to women and special juries. ${ }^{180}$

While it probably did not affect decisions in either opposition or affirmation of the Bill, interesting commentary was made about the implications of the definition of Maori in the principal Act. ${ }^{181}$ This noted that the actual formulation of the section meant that it only applied to Maori between half and full blood. ${ }^{182}$ Due to the evolution of the Maori race, that definition of Maori applied to very few. Therefore, while the arguments raged about the injustice and discrimination that the section had created, in reality most Maori were liable to serve on common juries and had been for many years. ${ }^{183}$ The real problem was that the Police had assumed that Maori were disqualified by the legislation and had never included Maori when compiling jury lists. ${ }^{184}$

Division was not over the general intention of the Bill but rather the timing. Most opponents felt that Maori were not yet ready for complete integration within the legal system. ${ }^{185}$ In recognition of this, it was proposed that if the Bill was passed at that session, the section abolishing all Maori juries would not come into force until December $1964 .{ }^{186}$

177 (20 November 1962) 332 NZPD 2757.

178 (20 November 1962) 332 NZPD 2757.

179 (20 November 1962) 332 NZPD 2759-2760.

180 (20 November 1962) 332 NZPD 2754-2755. Indeed, the government did not pass legislation that placed women on a completely equal footing with men until 1976, Juries Amendment Act 1976, s 2(3).

181 This was probably not instrumental in the debate because it did not really serve to advocate or oppose the abolition of the all-Maori jury provision. Advocates of the Bill could hardly point to the existing legislation as entirely discriminatory as this section showed that it was not (although they continued to do so). But opponents of the Bill would also have been reluctant to use this definition, as it would have meant that very few Maori would be entitled to use the all Maori jury. Rather, this point seems to have been raised just to show that the legislation had become outdated.

182 Jury Act 1908, s 2. See also, (20 November 1962) 332 NZPD 2751.

183 (20 November 1962) 332 NZPD 2751.

184 (20 November 1962) 332 NZPD 2751.

185 (20 November 1962) 332 NZPD 2760 and 2762-2765.

186 (11 October 1962) 332 NZPD 2013. 
This would give Maori time to show their opinion in the next election. This must have eventually been accepted as the best option as the Bill was finally passed in this form. ${ }^{187}$

\section{The Women's Question}

Agitation over including women in the jury system had begun as far back as $1896 .{ }^{188}$ But the first movement towards sexual equality in the New Zealand jury system was not until 1942 with the Women Jurors Act. This provision made little impact on numbers of women in the jury system. However, the response to the 1942 legislation was not entirely due to apathy and many people were still concerned that the jury system was inconsistent with the social status of women generally.

The length of the agitation for the inclusion of women in juries seems to indicate that while the issue was topical for a large group of New Zealanders, the majority of the public was relatively indifferent to this issue until the 1960s. However, it must be remembered that at this time the political "majority" in New Zealand was male. Notwithstanding these concerns, pressure for sexual equality became more acceptable and women were increasingly included in the jury system after the 1960s.

\section{Legislation}

The Women Jurors Act purported to grant any woman between the ages of 25 and 60 years the same rights and duties of jury service "as if she were a man". ${ }^{189}$ However, there was a proviso that held that a woman was placed on the jury list only if she "notifies the Sheriff in writing that she desires to serve as a juror". 190 That difference was substantial enough to incur condemnation from the National Council of Women of New Zealand as discriminatory ${ }^{191}$ and to be at least partly to blame for the enormously unequal numbers of women and men on the jury. ${ }^{192}$

Even with this large restriction on female entry into the jury system, there was little support for the Bill in its early stages. ${ }^{193}$ Perceptions of women as emotional, purely

187 Juries Amendment Act 1962, ss 1-2.

188 New Zealand National Council of Women (NZNCW) resolutions 1896.

189 Women Jurors Act 1942, s 2.

190 Women Jurors Act 1942, s 2.

191 NZNCW resolutions 1943.

192 "A new deal for those ladies of the jury." Auckland Star, 17 November 1976, 32 ["A new deal for those ladies of the jury"].

193 (8 May 1942) 261 NZPD 307. In fact it was only after the Prime Minister took up the Bill as a government paper that it was even granted a reading. 
domestic, and therefore clearly unsuitable for the constitutional role of juror were evident in early parliamentary debates ${ }^{194}$ and public opinion around this period. ${ }^{195}$

Even advocates of the Bill were influenced by these concepts of female frailty. In her introductory speech for example, Mrs Weaver noted that the Bill was not the product of "the popular call of feministic equality" but rather stemmed from the need to educate women about the "sins and sufferings of their own world". 196

More substantial arguments were provided however. The provision for women in the jury as early as 1919 in England was pointed to as proof that New Zealand women should be included in the jury. ${ }^{197}$ As was female opinion, when Mrs Weaver notes that "women of New Zealand in their thousands are behind the Bill". 198

It is clear that women's organisations supported the advancement of women into the jury service. ${ }^{199}$ However, Mrs Weaver's assertion that thousands of women supported the Act seems difficult to substantiate after looking at the statistics. After the Act was passed, only about 25 names of the 8000 on the jury list in 1943 were of women. ${ }^{200}$ In this case however, the formulation of the Act had as much to do with the lack of female representation on the jury as did female apathy.

194 (8 May 1942) 261 NZPD 307. Note for example the comment from Mr Lee who responded to comments about the perception of women as governed by the heart and not the head with "There is something to be said for that".

195 An article at the time notes the opposition in England with comments from solicitors about the "sickly sentimentality" of women and their tendency to be "too emotional, too nervous". "Where are all the Women Jurors?" The Evening Post, 9 January 1948, 10. [Where are all the Women Jurors?] In New Zealand a amusing example of this preconception of women appears in an advertisement for Parisian Ties which runs "The woman juror shook her head, He can't be guilty, so she said; He has such innocent blue eyes, And wears such smart Parisian Ties!"

196 (8 May 1942) 261 NZPD 307. To this end she also noted "the knowledge of evil need not make any one perverse in character or ideals, but rather should inspire one with a longing to help the fallen and to protect the innocent."

197 Sex Disqualification (Removal) Act 1919 (UK), s 1(b). However, this Act maintained effective exclusion of women as instead of excluding women from the outset, it included everyone and then provided for exemption of women through judicial discretion.

198 (8 May 1942) 261 NZPD 309.

199 NZNCW resolutions.

200 These statistics are from an article entitled "First Woman Juror" and is part of a collection of articles on women jurors held by Jan Jordon. Unfortunately, I have been unable to determine the origin of the article. However, other statistics from later newspapers have a similarly disproportionate number of male jurors within the system. "A new deal for those ladies of the jury" above n 195, 32 . 
The Act required women to physically go to the Sheriff and request to be placed on the list. Some commentators posited that this in itself was a humiliating experience and stopped many women from actively going forward. ${ }^{201}$ This formulation also ensured that only women who were aware, interested and able to get time off from work or family commitments could even get to the jury list stage. ${ }^{202}$ Little wonder then, that women were not rushing to fill the jury books with requests for inclusion. ${ }^{203}$

A further restriction was placed on women's attempts to gain juror status in the form of the peremptory challenge. ${ }^{204}$ The right of challenge to women was the same as for men ${ }^{205}$ but it is clear that it was used far more regularly and indiscriminately with regards to women. ${ }^{206}$ The Hon Mabel Howard noted this problem and questioned the appropriateness of the unofficial decrease in numbers of women in the juries. ${ }^{207}$ Newspapers also noted the rarity of an unchallenged woman. ${ }^{208}$ This seems to indicate the wide recognition that the challenge process was used to discriminate against women. It appears that between 1943 and 1960 only three women passed the barriers of having to volunteer and proceed unchallenged into the jury. ${ }^{209}$

This legislation therefore failed to quiet the repeated calls for more equality in all public institutions. For example the NZNCW initiated a constant bombardment of requests for

201 "Where are all the Women Jurors?" above n 198, 10.

202 The Wellington Professional Business Women's Club also noted the difficulty women had in getting out of work commitments to attend jury sittings. "Employers do not look favourably on women who volunteer for duty and are thus absent from their office where they perform such essential duties. "Where are all the Women Jurors?" above n 198, 10. Also note that commentary about the first woman juror, Elaine Kingsford, mentioned she too was having difficulty in getting out of work commitments to attend the session. "Woman Juror" Auckland Star, 15 October 1943, 5.

203 It is interesting to speculate whether the jury system would have existed had men been required to apply for the often-irksome task of service.

204 This problem does not seem to have been restricted to New Zealand however, with similar complaints being fielded in Britain. "'Where are all the Women Jurors?" above n 198, 10.

205 Juries Act 1908, s 115-126.

206 "Police check on early woman juror" North Shore Section, The Herald 5 August 1976, 6. Elaine Kingsford notes how disconcerting the practice of continual challenge was. Film Weekly Review 115 (1943)

207 (20 September 1961) 328 NZPD 2843.

208 "Jury Woman Sworn in Challenged When Called" Auckland Star 19 October 1943, 4; "Woman Juror is Unchallenged!" Auckland Star 5 May 1960, 1.

209 The Hon Mabel Howard stated that women had been allowed to serve on juries on only 2 occasions. (20 September 1961) 328 NZPD 2843. But the sum total from various newspaper reports note that at least 3 women made it onto the jury stand in this period. 
legislative change to Ministers ${ }^{210}$ and the Secretary for Justice, under the mandate of approximately 133, 000 women. ${ }^{211}$ They similarly urged members and women in general to overcome their fears and inhibitions and volunteer in large numbers for jury service. ${ }^{212}$ Despite all this however, women still seemed to feel restricted by the legislation and the social pressures against them and failed to volunteer in the numbers that would have made a noticeable difference to jury list ratios. ${ }^{213}$ Indeed, there were so few women appearing on juries that the press and court officials declared the first woman juror to be three different women over a period of 17 years. ${ }^{214}$

\section{Continued Debate in the 1960s}

The agitation did make an impact however, and Parliament again debated the issue at length in the 1960s. As had happened in 1942, there were contrasting opinions on the propriety of women in the public arena. ${ }^{215}$ Opposition was still based on the flawed assumptions that women were unwilling to be on juries, and that they were prevented from jury service in any case because of occupations as mothers and housewives. This time however, the promoters of women jurors advocated equality and the breaking down of incorrect assumptions about women rather than a patriarchal justification of women's involvement in a male dominated system. ${ }^{216}$

210 NZNCW resolution passed in meetings in 1945 to recommend to the Minister that women be called to service on juries in the same manner as men. Reaffirmed in 1946, 1947, 1948, 1953, 1954, 1956, and 1958.

211 NZNCW resolution 1954.

212 NZNCW resolution 1952.

213 For example even by 1948 there were only 11 women jurors on the Wellington list. "Where are all the women jurors?" above n 198, 10.

214 Mrs Elaine Robinson was clearly the first woman juror, gaining a seat in 1943. However, in 1948 Mrs Lettie Allen of Wellington was announced as the first woman juror. "Where are all the women jurors?" above $\mathrm{n} 198,10$. Moreover, in 1960, the paper that ran the original story about Mrs Robinson has Mrs Erica Wrightson as the first woman juror. "Woman Juror" above n 207, 5. Indeed, this article quotes Mr J Carrol the Supreme Court Registrar and Sheriff saying that Mrs Wrightson is the first woman juror in the Auckland Supreme Court, where Mrs Robinson had appeared 17 years earlier.

215 (20 September 1961) 328 NZPD 2841-2845. See the comments from both the Attorney-General the Hon Hanan, Mr Harker and Mr Edwards for the traditionally paternalistic approach in contrast to the Hon Mabel B Howard and Hon A H Nordmeyer for a more progressive view of equality for all.

216 (20 September 1961) 328 NZPD 2843. 


\section{Debates over Racial and Sexual Equality}

The debate over compulsory jury service for women corresponded with the debate over the abolition of the separate Maori juries. The justification of the abolition of the separate Maori system was couched in terms of equality and one law for all. ${ }^{217}$ However, these debates seemed to indicate that there should be one law only for all men, and advocates of sexual equality pointed to the inequality of this position. ${ }^{218}$ Similarly, the New Zealand government policy that required compulsory jury service for men and women in the Cook Islands was pointed to as illustrative of the New Zealand double standard. 219

\section{Legislative Equality}

Eventually, the arguments for equality were accepted in new legislation in 1963 which made jury service compulsory for both women and men. ${ }^{220}$ It even made provision for gender neutral language. ${ }^{221}$ However, once again there was a proviso that meant that women were not completely equal. ${ }^{222}$ The presumption of a domestic occupation for women allowed them to claim an exemption without giving any reason. ${ }^{223}$ Although this legislation did at least reverse the obligation of enrolling personally, it continued the gender distinction within the jury system. Jury service became a more easily accessible right but not the duty it was for men. Women's groups still agitated for change ${ }^{224}$ and it was not until 1976 that the controversial section was amended to create gender equality. ${ }^{225}$

\section{CONCLUSION}

The jury system has been a central feature of Common Law constitutions for hundreds of years. In New Zealand, the centrality of the system was reflected in both the speed with

217 (13 July 1961) 326 NZPD 500.

218 (20 September 1961) 328 NZPD 2843.

219 "Where are all the women jurors?" above n 198, 10.

220 Juries Amendment Act 1963, s 2(1).

221 Juries Amendment Act 1963, especially s 2(1) and s 4.

222 Juries Amendment Act 1963, s 4 (9).

223 Juries Amendment Act 1963 s 4(9).

224 NZNCW resolutions 1976.

225 Juries Amendment Act 1976 s 2(3). This Act repealed any remaining gender specific language and made room for exemption from jury service by request only for caregivers of children under the age of 6 years. A similar section exists under current legislation, which allows exemption from jury service on application for occupational, business, health, family or personal circumstances. Juries Act 1981, s 15(1)(a) and (b). 
which it was introduced and the importance placed on its use and regulation. Throughout its history, the New Zealand jury system has been adapted to the changing needs of New Zealand's social conditions.

Many of these changes were unheralded and the evolution of the New Zealand jury system is a difficult one to trace. Given the importance that was ascribed to this institution, the lack of commentary is an interesting feature of jury development. However, this is readily explained by the legislative practice of often passing significant amendments in obscure pieces of legislation. Moreover, notwithstanding the fact that the jury system was and still is regarded as a central part of the legal system, the actual task of jury service has rarely been regarded as a particularly exciting task. Similarly, it remained almost entirely uncontroversial for the main part of its history.

The three most controversial issues in jury development sprang from a discontinuity between the progress of the system and social development generally. The focus of this controversy was on the pursuit of equality within the legal system, which is an issue that remains controversial today. 226

While civil juries have declined in use, it seems widely accepted that the jury trial process should remain central in criminal cases. ${ }^{227}$ As calls are made for a re-evaluation of the current jury system, a reflection on its origins and development is both topical and necessary.

\section{APPENDIX}

A chronological list of legislation relating to New Zealand Juries

An Act to Provide for the Administration of Justice in New South Wales and Van Dieman's Land (UK) 9 Geo IV c 83

1841 Jury Ordinance

1841 Supreme Court Ordinance

1844 Jury Amendment Ordinance
1884 Supreme Court Ordinance and Supreme Court Rules

1844 Native Exemption Ordinance

1846 Resident Magistrates Court Ordinance

1861 Jury Ordinance Amendment

1862 Jury Law Amendment Act

1862 Supreme Court Amendment Act

1863 Jury Law Amendment Act

226 As commentators have noted that Maori are being disadvantaged by the current system. Juries in Criminal Trials above $\mathrm{n} 152,62-79$.

227 Timothy Brewer "Juries in Criminal Trials" (1998) NZLJ 255, 255. 


$\begin{array}{ll}1865 & \text { Provisional Jury List Act } \\ 1865 & \text { District Court Amendment Act } \\ 1868 & \text { Juries Act* } \\ 1870 & \text { Juries Act Amendment Act } \\ 1871 & \text { Juries Act } \\ 1874 & \text { Juries Act } 1868 \text { Amendment Act } \\ 1876 & \text { Juries Amendment Act } \\ 1878 & \text { Juries Act Amendment Act } \\ 1880 & \text { Juries Act* } \\ 1884 & \text { Supreme Court Act } \\ 1885 & \text { Volunteers Act } \\ 1886 & \text { Volunteer Amendment Act } \\ 1893 & \text { Criminal Code Act } \\ 1898 & \text { Juries Amendment Act } \\ 1908 & \text { Juries Act* } \\ 1908 & \text { Crimes Act* } \\ 1919 & \text { Juries Act } \\ 1939 & \text { Statutes Amendment Act } \\ 1942 & \text { Women Jurors Act } \\ 1945 & \text { Statutes Amendment Act } \\ 1949 & \text { Statutes Amendment Act } \\ 1950 & \text { Statutes Amendment Act } \\ * \text { Denotes Consolidating Legislation }\end{array}$

1951 Juries Amendment Act

1954 Crimes Act

1955 Judicature Amendment Act

1957 Summary Proceedings Act

1959 Juries Amendment Act

1960 Juries Amendment Act

1961 Crimes Act*

1961 Juries Amendment Act

1962 Juries Amendment Act

1963 Juries Amendment Act

1966 Juries Amendment Act

1967 Juries Amendment Act

1968 Juries Amendment Act

1974 Juries Amendment Act

1975 Juries Amendment Act

1976 Juries Amendment Act

1980 Crimes Amendment Act

1981 Juries Act*

1982 Juries Amendment Act

1985 Juries Amendment Act

1994 Juries Amendment Act 
